Arte, Individuo y Sociedad

ISSN: 1131-5598

\title{
Título: Muntadas : On Media Control
}

Editorial: Universidad de Cádiz

Autor: Diego Luna

ISBN: 978-84-9828-713-4

PVP: $19 €$

A comienzos de la década de los setenta Antoni Muntadas comenzó a interesarse —o mejor digamos, a preocuparse - por los medios de comunicación de masas como hecho social llamado a tener gran relevancia política. Lejos de cualquier mirada reduccionista - que por ejemplo tomara a los media como asunto de mera moda tecnológica- Muntadas encaró el problema de raíz, vale decir, sintió que podíamos estar ante auténticas herramientas de producción de subjetividades pasivas, de mecanismos de control social, y ante redes por las que discurre el poder. Desde el principio, Muntadas alertó con denuedo sobre la capacidad de seducción y manipulación, cuando no directamente de censura, que tiene la televisión en cualquier régimen político. Desde entonces y pegadas como siempre estuvieron a la actualidad, sus obras no han cejado en el esfuerzo por situarse en el corazón de las problemáticas que nos depara el neoliberalismo: el triunfo de la privatización y el individualismo; la espectacularización de las ciudades y la vida cotidiana; el desfase entre la libre circulación de capitales y el cierre de fronteras para las personas; el creciente uso del miedo como estrategia de dominio y un largo etcétera.

La reciente monografía sobre el autor, firmada por Diego Luna, constituye el mejor instrumento para adentrarse en la trayectoria de Muntadas, pues parte de un enfoque transversal que liga sabiamente las prácticas del catalán con toda esta madeja de cuestiones arriba esbozada. En este sentido, Luna establece un diálogo fluido entre Muntadas y las teorías de algunos de los pensadores contemporáneos más preclaros: hablamos de los análisis sobre el espectáculo y la hipermodernidad de Debord, Baudrillard, Bauman o Lipovetsky, las aportaciones sobre las paradojas de la globalización de García Canclini y Harvey, prestando especial atención a los estudios de Foucault sobre la «microfísica del poder». Tres alicientes más presenta el texto: primeramente, está estructurado siguiendo una cuidada selección de las obras más destacadas de Muntadas a la que acompaña un examen profundo de las mismas; además, Luna resalta la destreza del catalán para la investigación y crítica artística y sobre todo, para el despliegue de contra-prácticas y proyectos alternativos; por último, quisiéramos añadir que el ensayo cuenta con dos entrevistas a Muntadas donde se irán evidenciando las ideas principales que vertebran el estudio. En definitiva, Luna completa un libro que no solo habla de un artista de renombre, sino ante todo, habla de nosotros, de todos aquellos que estamos al otro lado de la pantalla, de nuestras sociedades y nuestros paisajes mediáticos, o sea, de nuestras vidas. 